\title{
The subject of behavior and dynamics of its states
}

\author{
Yury I. Alexandrov \\ Institute of Psychology RAS, Moscow, Russian Federation \\ E-mail: yuraalexandrov@yandex.ru
}

\begin{abstract}
Introduction. The concept of a "subject of behavior" (SB) was formulated within the system-evolutionary theory in systemic psychophysiology. It is argued that the development of the concept of SB requires describing other components of this internally consistent theory.

Theoretical Review. This section reviews the theoretical and empirical grounds used by V.B. Shvyrkov to formulate the original foundations of the concepts of SB and "state of the subject of behavior" (SSB). SB is defined as the whole set of functional systems (elements of subjective experience) comprising memory. SSB is defined as a section of functional systems (part of the whole set) that are formed at different stages of individual development and simultaneously actualized in order to provide the deployment of a certain step of the behavioral continuum. Behavior is considered as the dynamics of SSBs, i.e. the transition from the state corresponding to one behavioral act of the continuum to the state corresponding to the next behavioral act.
\end{abstract}

Results. This section reviews the results of theoretical and empirical development of the concepts of SB and SSB that was aimed to expand their factually supported meaning. This development has been implemented via the research paradigm of system psychophysiology representing a field of multidisciplinary studies focused on the mechanisms of formation and actualisation of experience in human and other animals during individual and collective behavior. I review neurogenetic bases of experience formation; dynamics of the formation of the structure of experience within a strategic game; variability of SSBs during consequent behaviors; the role of learning history during formation of the structure of experience; specific characteristics of various domains of experience; the unified theory of consciousness and emotion along with its implications; dynamics of SSBs underlying regression; properties of various forms of social interaction in individuals with holistic and analytical mentalities; the system mechanisms of moral judgement of actions; and results of mathematical modelling of SB formation.

Conclusions. Results of the reviewed studies of SB and SSB demonstrate heuristic value of these concepts and their potential as methodological tools for coordinated development in various fields of psychology and neuroscience. 


\section{Keywords}

brain, development, system, subjective experience, individual behavior, collective behavior, learning, regression, mind, consciousness, emotion

\section{Highlights}

- Subjective experience is represented by the models of individual and collective interactions with the environment, including the social environment, i.e. the systems (elements of subjective experience) that are formed in sequential acts of learning throughout the life span; the whole set of these systems form an individual's "subject of behavior" (SB).

- Current findings from interdisciplinary research of the structure of experience and its actualization, which is described as the transition from one "state of the subject of behavior" (SSB) (a specific set of systems actualized in a certain action) to another SSB, suggest that the concept of SB and SSB have great potential for development in psychology and neuroscience, integrating knowledge obtained from the studies of brain activity, behavior dynamics, and mentality in terms of the system-evolutionary theory.

\section{For citation}

Alexandrov Y. I. The subject of behavior and dynamics of its states. Rossiiskii psikhologicheskii zhurnal - Russian Psychological Journal, 2018, Thematic Issue 1 (Vol. 15, no. 2/1), pp. 131-150. DOI: 10.21702/rpj.2018.2.1.8

Original manuscript received 14.08.2018

\section{Introduction}

The concept of "subject of behavior" is a component of the system-evolutionary theory formulated by Shvyrkov as a development of the theory of functional systems of P. K. Anokhin in psychology, neuroscience and psychophysiology. It is clear that the disclosure of this concept involves at least a brief description of the other components of this internally consistent theory. In this article, I will start with this description, and then give a definition of the subject of behavior and its dynamics (in the process of unfolding of the behavioral continuum) as it was done by Vyacheslav Borisovich Shvyrkov. In the last part of the article I will describe the further development of this concept and the expansion of its empirically grounded content which were carried out in the course of realization of the multidisciplinary research program of the "Systemic Psychophysiology" scientific school $[1,2,3,4]$, formed on the basis of the laboratory of psychophysiology named after V. B. Shvyrkov at the Institute for Psychology, Russian Academy of Sciences. 


\section{Theoretical Review}

\section{System-evolutionary theory and the concept of «subject of behavior» as its component}

As the most important components of the factual basis of the systemevolutionary theory, V. Shvyrkov [1] considered: a) the establishment of specialization of neurones of different brain structures in relation to the systems formed during the mastery of behavioral acts at successive stages of individual development; b) the discovery of empirical arguments in favor of the fact that new organization of neurones, the impulses of which provide accomplishing a useful result of emerging behavior, is formed by selecting these neurons in the process of learning from the previously impulsively inactive ("silent") cells.; c) finding out the fact of simultaneous activation of neurones specialized in relation to systems of different "ages" (i.e. formed at different - early and late - stages of individual development), in the implementation of any behavior. Integration of these and other facts with the data and concepts available in psychology, physiology, neuroscience, ethology, sociology, genetics, anthropology, etc., allowed us to formulate the concepts of the system-evolutionary theory as follows.

"By interacting with the environment, the body deploys a genetic program of its own life cycle. Before the appearance of nervous system, interactions can be described by the following formula: genome $<->$ body <-> environment. The emergence of a developed nervous system (and the major part of the individual's genome is expressed in the cells of this very system) causes the modification of the above formula, turning it into: genome <-> brain <-> body <-> environment. Based on this modification, B. Shvyrkov considered the behavior as unfolding of the genetic program of the life cycle, which is "expressed" mainly in neurones. The nervous system in this case can be described not as a "body", but as a "subjective screen", which was formed during the evolution between the genetic program and its implementation, provided by bodily processes and changes in the interaction of the body with the environment" [5, p. 11-12].

"From the standpoint of these concepts, neurone is not a "coding element" or "combiner", but an "organism", which meets its needs with the help of metabolites, which come to it from other neurones, glial and other cells. Neurone impulse transmission occurs when there is a mismatch between the flow of metabolites from other cells and the metabolic needs of the neurone. These needs, in a situation of mismatch, determine the neural implementation of a special (impulse activity) way to change its connections with other cells, that at the whole organism level can (in case of activity coordination between this and many other neurones) act as an unfolding of individual behavior, aimed at achieving a holistic result, and provide "need-related" change in metabolic (including synaptic) inflow to this (and other) neurone(s). 
The structure of "innate acts" manifests the history of adaptive interactions between organism and environment in the course of evolution. The neurones specialized in the systems of these acts are found more frequently in the relatively older structures of the central nervous system.

In the cortical structures of the brain there is a significant reserve of "silent" neurones. These cells are employed to form new behavioral acts. A set of these cells if selected from the previously silent neurones that provide activations in the test acts, and only those cells are selected whose activation provides the result of the formed act. Fixation of the new act system is realized through specialization of reserve neurones in relation to this system and strengthening of cell connections of new and previously formed behavior (this very condense formulation of the idea of the patterns of a new behavior formation was called the system-selection hypothesis of learning) [6, p. 125].

The systems of acts of behavior accumulated in the phylo- and ontogeny form the structure of the individual's subjective world. In this world there are no special neural "mechanisms of perception", "movements control", etc. Therefore, the analysis of the systemic specializations' composition and the dynamics of the neural impulsation can be considered an objective method for studying the structure and dynamics of the subjective world per se.

The nature of the implemented behavior is associated with a set of memoryextracted and simultaneously activated systems of different "ages", and their relationships (intersystemic ones) can be studied using both qualitative and quantitative methods.

"The emergence of human consciousness is inextricably linked with the formation of human community. The formation of the latter, probably, caused even greater modification of the relationships between the organism (person) and the environment than the development of the nervous system. The new relations are expressed by the following formula: genome $<->$ brain $<->$ body $<->$ cultural environment $<->$ society $<->$ universe. Therefore, the idea of the structure of the subjective world of a human being can be obtained by comparing the data obtained both with the help of brain activity mapping, and through the analysis of the structure of social consciousness, which elements are "assimilated" by the individual and transformed into individual knowledge. These elements include knowledge about "mental processes", such as perception, will, emotions, etc., which are actually products of social consciousness, formed as characteristics of the individuals' external behavior for practical purposes of the organization of interactions between society members. Not only the above, but also other concepts that describe the subjective reality, probably correspond to certain systemic states. It is these systems, and not from other "processes" (different for different psychologists) that constitute an individual's subjective world. A study 
of the systemic states and "intersystemic relations algebra" can be considered to be a general task of systemic psychophysiology" [5, p. 13].

\section{The structure of the subjective world and the subject of behavior}

The conclusion of fundamental importance for psychophysiology, which follows from the above, is that the study of brain activity, especially its individual neurones, is the way to an objective analysis of subjective reflection. This is so because the specialization of neurones with respect to the elements of individual experience (functional systems) means that their activity reflects not the outside world as such, but the connections, interaction with the individual. Therefore, studying the systemic specialization of neurones is an adequate method for the description of the subjective world proper.

From the considered positions, the subjective world turns out to be a structure that, as noted above, includes functional systems accumulated in the course of evolution' and individual development.

In this regard, the term "subject of behavior" refers to the entire set of functional systems that make up the memory of the individual. The "the subject of behavior state" is understood as a part of this set - a set of systems formed at different stages of individual development and simultaneously actualized to

\footnotetext{
1 "Accumulated in evolution in comparison with" individually specific "does not imply that the first are given to the individual as ready-made "bricks" of the structure of individual memory and in this sense are innate. There is considerable stock of literature devoted to the analysis of the meaning of the seemingly clear term "innate". It is effectively integrated in the theoretical work of R. Samuels [7]. As Samuels, in particular, notes, properties are often considered innate, if they are not acquired. Acquired are such properties that appeared during a certain period of development of the individual, until which they were absent. From the standpoint of this "perfectly sound understanding of acquisition", "all the cognitive structures are acquired", or let us formulate it differently - if "innate properties are those that are not acquired", then "there are no innate cognitive properties" [7, pp. 136, 137]. Our systemogenetic views are consistent with this approach. In accordance with them, any relationship with the environment, even the one that is species-specific (peculiar to all individuals of this species) as well as individually specific ones (appearing in connection with the peculiarities of the individual life history in some of the species representatives, but not in other individuals) is provided by the activity of specialized neurones, and their specialization occurs in the process of learning. This means that it is necessarily formed in the process of individual development, which represents a sequence of systemogenesis. In other words, any "innate" behavior does not exist initially in the form of a readymade "brick" ("body part", "alphabet", integration, network, system, etc.), but is formed in the process of individual development, is in this sense acquired and carries the features of this development (see, for example: [8]). As for the difference between species-specific and individual-specific behavior, we can say the following. In early ontogenesis different groups of specialized neurones are formed due to selection. Then, in the process of learning (systemogenesis) the second stage of selection gets shaped, culminating in the specialization of the neurone in relation to the system of a particular act. Apparently, the pre-specialization of neurones intended for ancient systems of species-specific acts, in contrast to individually specific ones, is relatively rigid (but not absolute; see, for example: [9]) and determines what specific act they will be specialized for in the process of learning.
} 
ensure the deployment of a specific stage of the behavioral continuum. A set of systems of different "age", the actualization of which constitutes the basis for achieving an adaptive result of a particular act of behavior, represents a unit of individual experience, and the system represents its element.

\section{The dynamics of the subjective world as shift of the subjects of behavior states}

"Behavior can be understood as an unfolding of a behavioural continuum, that is, a sequence of behavioural acts in which an individual act appears to be part of a continuum concluded between two outcomes: the preceding and the given acts. Thus, adjacent acts are joined by the transitional processes that unite them, which simultaneously represent an assessment of the result achieved in the previous act and the organization associated with this assessment, with planning of the next act" [10, p. 263]. Then the dynamics of the subjective world becomes a transition from one state of the subject of behavior to another in the behavioral acts shifts, which correspond to these states, and also represents the transitional processes, as a substitution of one set of systems with another.

\section{Results}

Experimental and theoretical development of ideas about the subject of behavior and its states

Below one can see representative examples that demonstrate the results of the development of ideas about the subject of behavior and its states in the scientific school "System psychophysiology" briefly discussed above (4; look http://www.ipras.ru/cntnt/rus/institut p/nauchnye s/nauchnaya 2.html).

\section{Neurogenetic patterns of the experience structure formation}

We have demonstrated that the expression of early genes, in particular, the early C-fos gene, can serve as a sign of the process of neurone specialization formation in relation to systems that through the learning process get included in the structure of experience characterizing the subject of behavior. It was found that the distribution of the expression product of this gene (protein c-Fos - transcriptional factor, inducing changes in the expression of other genes and leading to changes in the protein phenotype of the neuron) in the animal brain corresponds to the distribution of neurones specialized in relation to the acquired element of the experience of food-seeking behavior [11]. It was found that the subject of behavior state (the composition of actualized systems) in learning depends on the experience that the animal possessed before training [12]; the organization of the experience formed before this episode of learning is modified by learning through the 
processes of accommodation reconsolidation $[13,14]$. Thus, the subject of behavior in learning is modified both by the inclusion of new systems in its composition, and by the reorganization of systems formed at the previous stages of individual development.

The dynamics of the experience structure formation in the strategic game and the problem of the rational vs. intuitive

In the descriptions of formation patterns and dynamics of sets of systems typical for certain states of the subject of behavior, the concepts of "opposition" or "reciprocity" are used, denoting a complete or partial ban on the simultaneous actualization of interacting systems, as well as the concept of "synergy" as a characteristic of systems juxtaposition that provides the possibility of their simultaneous actualization in one set.

The use of mathematical apparatus of relational algebra [15] gave grounds for a more detailed consideration of these relations. In studies of the formation of two zero-sum and full-information partners in the strategic game, two groups of relations between the components of experience were identified. The first group of relations provides a sequence of components actualization, linking them into a "semantic propositional network" (SPN), which represents "strict order" relations, forming stable linear sequences and "non-strict order" relations that create loops and cycles on SPN [16]. The relations of the second group form a "semantic associative network" (SAN); they link components into groups or define demarcation between sets of components, restricting or prohibiting simultaneous updating of some of these sets. It is established that the processes of formation of SPN and SAN are asynchronous. Studies show that in similar behavioral situations different states of the subject of behavior get shaped on a consistent basis and the order of change of these states in individuals prone to predominantly "rational" or "intuitive" method of solving test problems, differs [17].

Variability the subject of behavior states in successive implementations of behavior

Insofar as neurones are specialized with respect to systems, with the help of recording the impulses of neurones in the unfolding of behavior, it is possible to establish what kind of system - elements of experience are actualized at each of the behavioral stages. It was found out that in the implementation of this behavioral act the subject of behavior state is represented as a group of systems, invariably (in all implementations) actualized in the unfolding of this act, and a group of systems, the composition of which varies from one implementation of the same looking act to another. At the same time, the 
systems of the second group can always be involved in other acts of individual behavior. The variability of the subject of the behavior state characteristic of this act is associated with the complexity of intersystem and interneuron relations, which, apparently, can not be reproduced twice in an exact form. Indeed, even if we use the criterion of motor characteristics, re-implementing of the acts turns out to be "repetition without repetition" [18]. P. Anokhin [19] also stressed that the parameters of the result obtained in the implementation of behavior can not match the model formed in the acceptor of the action results with "mathematical accuracy".

Modification of the subject of behavior state means that when reproducing externally "the same" action, subjective world is not the same. The analysis of impulse activation of brain cells, representing the actualization of those systems, in regards to which these cells are specialized, allows to reveal qualitative and quantitative regularities, describing the dynamics of the state of the elements of experience, which determines the specified variability of the subjective world. Based on the data obtained in the course of such an analysis [20], it is established, for example, that 1) the severity of changes in the subject of behavior state in the implementation of successive implementations of the same (by the criterion of the achieved result) behavior is associated with the history of the formation of this behavior in learning and that 2) the variability affects relatively "newer" systems, i.e. those that were formed at later stages of individual development.

It was discovered that the subject of behavior state changes not only in successive implementations of externally identical behavior after changing the method of obtaining the result, but also when considering the states at much longer intervals. Thus, in animals, the lobes of neurones specialized in the approach to the pedal (pressing on which leads to appearance of a full feeder) and with respect to the approach to the feeder differed between the first and second weeks of the experiment with instrumental food-seeking behavior of animals [21].

Therefore, similarly looking acts of behavior at different stages of learning can correspond to different subject of behavior states. It is also found that changes in the subject of behavior state at successive stages of memory consolidation have an impact not only on the composition of activated systems, but also on the relations between the systems - intersystemic relations [22].

\section{The subject of behavior state and the history of learning}

We have found that different sequences of the stages of the same cyclic instrumental behavior are characterized by different actualization of the systems that as a result of learning make up the subject of behavior state. The results 
showed that these differences relate to the above-mentioned dynamics of inter-systemic relations, in this case - the relations between the systems of the current behavior and systems of other behaviors implemented in the same environment. It is shown that in the nonspecific activity of specialized neurones (that reflects the aforementioned intersystem relations) the history of behavior formation is recorded, i.e. this activity (and hence intersystem relations) differs when we compare animals whose resulting behavior has a different history of formation [23].

In other experiments, it was discovered that the characteristics of the subject of behavior state are related to how the animal is trained to this (similarlylooking) behavior: in one or many stages. After multi-stage animal training in instrumental food-seeking behavior, this behavior activated more neurons involved that specialized in acts formed in the training of this behavior (neurones of "new" systems) than it happened in animals that learned similar behavior in one session [24].

The subject of behavior state and domains of individual experience

In special experiments conducted with the registration of neuronal activity in animals, we analyzed the relationship between different domains of individual experience (by which we mean sets of systems related to the commonality of the results achieved). It was found that systems from the domain of one form of behavior can be updated when performing acts of another domain. The differences in the number of relations between the systems of one domain of individual experience and systems belonging to different domains [25] are revealed. Thus, it is confirmed that the state of the subject of behavior includes systems of acts of the same form of behavior as well as the system of acts of other forms of behavior in an actualized form.

Relations between different domains of experience were studied in humans as well: they were studied in the experiments with semantic priming [26]. It is shown, in particular, that an essential factor determining the characteristics of the state of the subject of behavior is the number of systems in the domain of experience, the elements of which are actualized as a part of the composition of this state.

Systems of different "age" in the structure of the subject of behavior states and their psychological characteristics: a unified concept of consciousness and emotions

The unified concept of consciousness and emotions that we suggested [27-31] uses a non-disjunctive approach to the analysis of the problem of consciousness and emotions. The essential moment for the theory 
is the statement reasoned by us and other authors, according to which successive systemogenesis, the formation of new systems in the processes of learning throughout individual development, is associated with an increase in the differentiation of the interaction of the individual and the environment. "Consciousness and emotions are the characteristics of different systems that are part of the subject of behavior state, which belong to different levels of the system organization of behavior. These levels are transformed stages of development of the individual, which correspond to relatively higher and lower levels of systemic differentiation. Emotions characterize the actualization of relatively "old" systems formed at the earliest stages of ontogenesis and correlated with the minimum level of differentiation: "good bad" (approach - withdrawal). Consciousness characterizes the actualization of those relatively "new" systems, the formation of which in the later stages of ontogenesis provides an increase in the differentiation of individual's interactions" [32, p. 16-17]. In a number of experiments it was demonstrated that the change in expression of more or less differentiated systems in the state of the subject of leads to a corresponding change in the severity of these characteristics.

For over than twenty years we have been using this theory for the formulation of hypotheses and interpretation of results in various problem fields of psychology. An example of its application to the study of the connections between the language, the development of behavior in ontogenesis and emotions represented in a series of works [33-35], in which it is shown that if a person is offered to imagine (mentally realize) early-formed types of behavior, for example, those associated with olfactory and taste sensations or sensations of the skin, this person will assess the emotions that arise in this case as more intense than when he or she is presented with late-formed types of behaviors associated with visual, auditory or tactile sensations.

The difference is associated with different contributions (larger for the types of behavior of the first group) of low-differentiated systems in the subject of behavior state associated with the actualization of experience in the internal plan. In addition, the decision-making time when assessing the presented behavior also corresponded with the characteristics of the subject of behavior state: if a person represented early-formed behaviors, he or she evaluated them faster than late-formed ones. This pattern was probably due to the fact that earlier formed behaviors are provided with a smaller number of functional systems, than the ones generated later, and the updating of a smaller number of systems takes less time.

Another example is our formulation of the ideas about the system basis of regression. 
Reversible dedifferentiation as a characteristic of the subject of behavior state typical of regression

Regression is usually understood as a decrease in the "level of organization" of behavior, a kind of return of the individual to the earlier stages of development. We conducted both theoretical and empirical analysis of the dynamics of system organization of behavior, based on the results of interdisciplinary research (from neurodevelopmental and neurophysiological studies in animals to studies of prosocial behavior in healthy adults and children, and also people suffering from chronic disease) to conditions in which there is regression: stress, illness, learning disability, emotional status and alcohol intoxication [36-40], allowed us to detect the similarity of the regularities underlying regression in these situations. In all of these situations, the subject of behavior state could be described as reversible dedifferentiation: a transient relative increase of expression of low-differentiated systems in the actualized experience. We have argued that it is the systemic ("developmental") value of dedifferentiation, "phenomenologically described as regression and being a common mechanism for restructuring the interaction of the organism with the environment in different situations in which past patterns of behavior have become ineffective, is the most significant factor that plays role not only in its consolidation it the course of evolution as a component of stress adaptation, but also in general its occurrence in those situations, which involve the formation of a new and major modification of existing adaptations in a changing external and/or internal environment" [40, p. 87].

Holistic and analytic nature of thinking as a culturally specified characteristic of the subject of behavior

A large amount of data accommodated in the literature allows us to believe that one of the key characteristics of the human mentality, including the fact of its cultural or subcultural embeddedness, is the analyticity-holisticity of thinking [41, 42]. Analyzing the co-evolution of the mentality types and institutional matrices, we can argue in favor of the predominant development of holistic strategies in non-Western countries, which are dominated by cooperative forms of interaction, and of analytical ones in the West, with a predominance of competitive forms of interaction $[43,44]$.

We have demonstrated that the systemic organization of behavior associated with competitive and cooperative forms of social interaction is different for subjects with analytical and holistic thinking. It turned out, that the holistic subjects expressed greater sensitivity to different forms of social interaction $[45,46]$. It is revealed that for subjects with analytical thinking the process of actualization of systems within the subject of behavior state goes 
on faster in competitive forms of interaction, and for subjects with holistic thinking - in cooperative ones.

\section{The subject of behavior and moral assessment of actions}

Moral assessment of actions is an important component of adaptive human behavior in society and is viewed from our point of view as a characteristic of the individual's integral behavior [9]. Features of moral assessment are determined by the set of systems that make up the structure of the subject's experience, and inter-system relationships that are associated with assessment (self-report) of one's own behavior with the eyes of an external "observer" (society). Moral assessments change with age and are specific for men and women [47, 48], as well as for representatives of different cultures [48]. Our results indicate that the moral assessment is based on the actualization of systems of different ages and degrees of differentiation: intuitive assessment of actions, which the subject learns from an early age, is based on the actualization of mostly low-differentiated experience and takes place in a similar form among representatives of different socio-cultural groups; rational evaluation of actions is provided mainly by actualization of highly differentiated experience, formed at later stages of individual development of the subject, and has a pronounced socio-cultural specificity. Using alcohol as a factor of controlled experimental influence on the subject of behavior state (selective oppression of actualization of the most differentiated systems), we have demonstrated that moral assessment is carried out mainly intuitively on the basis of actualization of low-differentiated systems, in the very first place alcohol inhibits the processes of rational reasoning, without disturbing the intuitive assessment of actions [49]. In addition, in the situation of moral evaluation, alcohol intake was associated with changes in the dynamics of the heart rate (increase in heart rate and decrease in RR-interval variability), which can be considered a physiological indicator of systemic dedifferentiation - a reversible decrease in the contribution of the activity of highly differentiated systems to behavior [50,51].

We also analyzed the formation of a sense of justice in 4-11 years old children in terms of changes in the subject of behavior. The analysis is based on the results of the study of solutions of moral dilemmas "friend" - "stranger" in the situation of the implementation of behavior aimed at coordinating the opponent's goals: providing assistance to a member of his group when one is not obliged to, because he is a "friend", and vital assistance to a member of another group. The arguments are given that the decision in favor of "friend" is based on the actualization of the older systems that underlie parochial altruism, nepotism, etc., while the basis of the choice of assistance 
to the "stranger" is the actualization of the later formed systems. In favor of this assumption, evidence suggests that older children prefer to help the "stranger" than younger children much more often [52]. The subject of behavior state in the implementation of later formed behavior (decision in favor of "stranger") is characterized by a pronounced "intersystem mismatch", which is manifested in a greater value of the index of vegetative balance in children, who more often side with a "stranger" than in children, who more often side with their "friend". Probably, this mismatch reflects the processes of learning and exists due to the implementation of the newly formed behavior, provided by the actualization of systems of different age, aimed at achieving previously agreed goals [53]. It can be assumed that an important role in the actual subject of behavior state is played by conscious control of one's own behavior, i.e. an internal report «in front of the society» (see above - "observing" society) on the compliance with moral norms, i.e. on compliance of the result achieved by an individual with the "collective result" of society [9]. Thus, the decrease in the level of conscious control of one's own behavior in the absence of visible external control in the face of the experimenter during the solution of moral dilemmas leads to the implementation of earlier formed behavior, an increase in the share of support to one's "friend" [54]. Moreover, stress, which blocks the actualization of more differentiated systems of behavior that was formed relatively late [38], causes regression of adults, as a rule, in the control of choosing the option of vital assistance to a member of someone else's group - to an "alien", to the "childish" method of making decisions: "my close people are always right" [55].

Mathematical modeling of patterns of the subject's of behavior formation and the dynamics of its state

With the help of mathematical modeling it was shown that the subject, by actively interacting with the environment in which it is located, spontaneously transforms it so that the objective laws of the environment change for him in the process of his activity in this environment [56]. In particular, the probability of occurrence of a certain situation in the environment (for example, the appearance of a "food object" in the field of view) is not fixed, but depends on the behavior of the subject and his skills of interaction with the environment and can significantly change in the learning process. Similarly, the regularities of the action - result ratio vary greatly: the probability of achieving the goal by a certain action (for example, the probability of successfully approaching the object from the left by the action of turning to the left).

There are some arguments in favor of the fact that it is necessary to study the behavior of the active subject by the method of immersion into 
the environment [57], and not, for example, by the method of presenting incentives, in which the laws of the environment are fixed, and the subject is deprived of the opportunity to influence the environment. The results of the study of the behavior of model agents are consistent with the results obtained by us (see above) in the study of "natural" agents - people and animals: individuals who have a different history of formation of the subject of behavior structure and placed in the same environment, interact with it in different ways, and the laws of this environment are different for them depending on what skills they have learned in it [56].

In the research with the help of using mathematical modeling of the dynamics of the subject of behavior state, it is shown that if the actualization of the elements of experience (systems) is primary and determines the behavior, i.e. the dynamics of actualization of the elements of experience has immanent causes and is not determined solely by the external situation, the behavior can have fractal characteristics. Such a pattern can be considered in connection with the mechanism of "internal causality" and activity in the subject [58].

\section{Conclusions}

The above review of the results (both theoretical and empirical) of the use of the concept of "subject of behavior" and "the subject of behavior state" showed that they can be applied in order to

- analyze the laws of formation and actualization of the subjective experience of people and animals in individual and collective (competitive and cooperative) behavior;

- interpret the results obtained in field and model experiments;

- to study prosocial behavior in adults (belonging to different cultures and social groups) and its development in ontogenesis;

- to identify the mechanisms of influence of stress and alcohol on the systemic organization of behavior;

- to form a system-evolutionary understanding of the relationship of consciousness and emotions, as well as the value of regression as a stage of development;

- to examine the relationships between language acquisition and the development of behavior in ontogenesis and emotions;

- to describe differences between behaviors of approaching and avoidance as specifics of the properties of systems belonging to the matching domain experience;

- to establish a link between the history of mastering a certain behavior and the structure of the experience underlying this behavior; etc. 
Analysis of the results of using the concepts of "subject of behavior" and "the subject of behavior state" shows that they can be successfully used to conduct research in a variety of problem fields of psychology and neuroscience, and also demonstrates the high heuristic efficiency of these concepts.

\section{Acknowledgments}

Supported by a grant from the Federal Agency for Scientific Organizations of the Russian Federation (project no. 0158-2017-0002), the research program of the System Psychophysiology leading scientific school of the Russian Federation (SS-9808.2016.6).

\section{References}

1. Shvyrkov V. B., Alexandrov Y. I. (eds.) Vvedenie v ob"ektivnuyu psikhologiyu. Neironal'nye osnovy psikhiki [Introduction to objective psychology: Neuronal basis of mind]. Moscow, Institute of Psychology RAS Publ., 1995. 164 p.

2. Alexandrov Yu. I. Systemic psychophysiology. In: Chris Forsythe et al. (eds.) Russian Cognitive Neuroscience: Historical and Cultural Context. N.Y.: Create Space Independent Publishing, 2015, pp. 65-100.

3. Alexandrov Yu. I., Krylov A. K., Arutyunova K. R. Activity during learning and the nonlinear differentiation of experience. Nonlinear Dynamics, Psychology, and Life Sciences, 2017, Vol. 21, no. 4, pp. 391-405.

4. System psychophysiology. In: Vedushchie nauchnye shkoly Rossii [Russian leading scientific schools]. Moscow, Yanus-K Publ., 1998. 547 p.

5. Alexandrov Yu. I. Advancing the time: introduction. In: V. B. Shvyrkov Yu. I. Aleksandrov (eds.) Vvedenie v ob"ektivnuyu psikhologiyu. Neironal'nye osnovy psikhiki [Introduction to objective psychology: Neuronal basis of mind]. Moscow, Institute of Psychology RAS Publ., 1995, pp. 5-28.

6. Aleksandrov Yu. I. V. B. Shvyrkov as the originator of a new scientific worldview (on his seventieth birthday). Psikhologicheskii zhurnal, 2009, Vol. 30, no. 4, pp. 123-126 (in Russian).

7. Samuels R. Innateness in cognitive science. Trends in Cognitive Sciences, 2004, Vol. 8, no. 3, pp. 136-141. DOI: 10.1016/j.tics.2004.01.010

8. Alexandrov Y. I. Moral' i geny. Predislovie k knige M. Khauzera Moral' i razum [Morality and genes: Preface of the Moral Minds book by M. Hauser]. Moscow, Drofa Publ., 2008, pp. 5-17.

9. Aleksandrov Yu. I., Aleksandrova N. L. Sub"ektivnyi opyt, kul'tura i sotsial'nye predstavleniya [Subjective experience, culture, and social representations]. Moscow, Institute of Psychology RAS Publ., 2009. 319 p.

10. Aleksandrov Yu. I. System psychophysiology. In: Psikhofiziologiya [Psychophysiology]. St. Petersburg, Piter Publ., 2011, pp. 252-309. 
11. Svarnik O. E., Alexandrov Yu. I., Gavrilov V. V., Grinchenko Yu. V., Anokhin K.V. Fos expression and task-related neuronal activity in rat cerebral cortex after instrumental learning. Neuroscience, 2005, Vol. 136, no. 1, pp. 33-42. DOI: 10.1016/j.neuroscience.2005.07.038

12. Svarnik O. E., Bulava A. I., Alexandrov Y. I. Expression of c-Fos in the rat retrosplenial cortex during instrumental re-learning of appetitive bar-pressing depends on the number of stages of previous training. Frontiers in Behavioral Neuroscience, 2013, Vol. 7, pp. 1-7. DOI: 10.3389/fnbeh.2013.00078

13. Alexandrov Yu. I., Grinchenko Yu. V., Shevchenko D. G., Averkin R. G., Matz V. N., Laukka S., Korpusova A. V. A subset of cingulate cortical neurons is specifically activated during alcohol-acquisition behaviour. Acta Physiologica Scandinavica, 2001, Vol. 171, no. 1, pp. 87-97. DOI: 10.1046/j.1365201X.2001.00787.x

14. Svarnik O. E., Anokhin K.V., Aleksandrov Yu. I. Experience of the first"whiskerdependent" task influenced c-Fos induction in rat barrel cortex neurons during acquisition of the second "whisker-independent" task. Zhurnal vysshei nervnoi deyatel'nosti im. I. P. Pavlova - I. P. Pavlov Journal of Higher Nervous Activity, 2014, Vol. 64, no. 1, pp. 77-81 (in Russian). DOI: $10.7868 /$ $\underline{\mathrm{S} 0044467713060178}$

15. Osipov G. S. Priobretenie znanii intellektual'nymi sistemami: Osnovy teorii i tekhnologii [Knowledge acquisition by intelligent systems: Basics of the theory and technology]. Moscow, Nauka, Fizmatlit Publ., 1997. 112 p.

16. Aleksandrov I. O. Formirovanie struktury individual'nogo znaniya [Formation of the structure of individual knowledge]. Moscow, Institute of Psychology RAS Publ., 2006. 560 p.

17. Maksimova N. E., Aleksandrov I. O., Tikhomirova I. V., Filippova E. V. Typology of the intuitivity-rationality and forming of the individual knowledge structure. Psikhologicheskii zhurnal, 2001, Vol. 22, no. 1, pp. 43-60 (in Russian).

18. Bernshtein N. A. Fiziologiya dvizhenii i aktivnost' [Physiology of movements and activity]. Moscow, Nauka Publ., 1990. 494 p.

19. Anokhin P. K. Filosofskie aspekty teorii funktsional'noi sistemy [Philosophical aspects of the theory of functional systems]. Moscow, Nauka Publ., 1978. $400 \mathrm{p}$.

20. Aleksandrov Yu. I., Shevchenko D. G., Gorkin A. G., Grinchenko Yu. V. Dynamics of system organization of behavior in its sequential realization. Psikhologicheskii zhurnal, 1999, Vol. 20, no. 2, pp. 82-89 (in Russian).

21. Sozinov A. A., Grinchenko Yu. V., Kazymaev S. A., Aleksandrov Yu. I. Pokazateli stabil'nosti i dinamiki mozgovogo obespecheniya novogo povedeniya [Stability and dynamics of brain mechanisms for new behavior]. Nelineinaya 
dinamika v kognitivnykh issledovaniyakh - 2015. Trudy IV Vserossiiskoi konferentsii [Proc. the IV All-Russian Conference"Nonlinear dynamics in cognitive studies - 2015"]. Nizhny Novgorod, Institute of Applied Physics RAS Publ., 2015, pp. 220-222.

22. Kuzina E. A., Aleksandrov Yu. I. Multiple repetition of instrumental behavior and the reorganization of its cerebral mechanisms. In: A. L. Zhuravlev, V. A. Kol'tsova Fundamental'nye i prikladnye issledovaniya v sovremennoi psikhologii [Fundamental and applied research in modern psychology]. Moscow, Institute of Psychology RAS Publ., 2017, pp. 1583-1591.

23. Gorkin A. G., Shevchenko D. G. Distinctions in the neuronal activity of the rabbit limbic cortex under different training strategies. Zhurnal vysshei nervnoi deyatel'nosti im. I. P. Pavlova - I. P. Pavlov Journal of Higher Nervous Activity, 1995, Vol. 45, no. 1, pp. 90-100 (in Russian).

24. Kuzina E. A., Aleksandrov Yu. I. Aktivnost' neironov retrosplenial'noi kory krys v povedenii, sformirovannom s raznym kolichestvom etapov obucheniya [Neuron activity in the rat retrosplenial cortex in the behavior formed with various numbers of learning stages]. Sbornik tezisov: Dvenadtsatyi Mezhdunarodnyi Mezhdistsiplinarnyi Kongress "Neironauka dlya meditsiny i psikhologii" [Proc. the 12th International Interdisciplinary Congress "Neuroscience for medicine and psychology"]. Sudak, 2016, pp. 235-236.

25. Gorkin A. G., Rozhdestvin A. V., Chistova Yu. R. Reconstructing relationships between the components of subjective experience by the activity of specialized neurons. Neirokomp'yutery: razrabotka, primenenie - Neurocomputers: Development and Application, 2015, no. 4, pp. 29-30 (in Russian).

26. Bezdenezhnykh B. N., Marchenko O. P. Categorization of words as a way of studying intersystem relations. Psikhologicheskii zhurnal, 2008, Vol. 29, no. 3, pp. 77-85 (in Russian).

27. Aleksandrov Yu. I. Soznanie i emotsii [Consciousness and emotions]. Teoriya deyatel'nosti i sotsial'naya praktika: 3-i mezhdunarodnyi kongress [Proc. the 3rd International Congress "Theory of activity and social practice"]. Moscow, Fizkul'tura, obrazovanie, nauka Publ., 1995, pp. 5-6.

28. Aleksandrov Yu. I. From emotions to consciousness. In: D. V. Ushakov (ed.) Psikhologiya tvorchestva: shkola Ya. A. Ponomareva [Psychology of creativity: I. V. Ushakov's school]. Moscow, Institute of Psychology RAS Publ., 2006, pp. 293-328.

29. Alexandrov Yu. I. Psychophysiological regularities of the dynamics of individual experience and the "stream of consciousness". In: C. Teddei-Ferretti, C. Musio (eds.) Neuronal bases and psychological aspects of consciousness. Singapour, N.Y., London, Hong-Kong:"World Scientific", 1999, pp. 201-219. DOI: $\underline{10.1142 / 97898143132540017}$ 
30. Alexandrov Yu. I. Comparative description of consciousness and emotions in the framework of systemic understanding of behavioral continuum and individual development. In: C. Teddei-Ferretti, C. Musio (eds.) Neuronal bases and psychological aspects of consciousness. Singapour, N.Y., London, Hong-Kong: “World Scientific", 1999, pp. 220-235. DOI: $10.1142 / 97898143132540018$

31. Alexandrov Yu. I., Sams M. E. Emotion and consciousness: Ends of a continuum. Cognitive Brain Research, 2005, Vol. 25, no. 2, pp. 387-405. DOI: 10.1016/j.cogbrainres.2005.08.006

32. Aleksandrov Yu. I. Regularities of actualization of individual experiences and reorganization of its systemic structure: a complex investigation. Trudy ISA RAN-Proceedings of ISA RAS, 2011, Vol. 61, Issue 3, pp. 3-25 (in Russian).

33. Kolbeneva M. G., Aleksandrov Yu. I. Organy chuvstv, emotsii i prilagatel'nye russkogo yazyka. Lingvo-psikhologicheskii slovar' [Sense organs, emotions, and adjectives in Russian: Linguistic and psychological dictionary]. Moscow, Yazyki slavyanskikh kul'tur Publ., 2010. 368 p.

34. Kolbeneva M. G., Myagchenkova M. A., Aleksandrov Yu. I. Characteristics of the mental reactivation of tactile experience in patients with chronic tensiontype headache. Psikhologicheskii zhurnal, 2017, Vol. 38, no. 3, pp. 66-80 (in Russian). DOI: $10.7868 /$ S0205959217030060

35. Kolbeneva M. G., Aleksandrov Yu. I. Mental reactivation and pleasantness judgment of experience related to vision, hearing, skin sensations, taste and olfaction. PLOS ONE, 2016, Vol. 11, no. 7, e0159036. DOI: 10.1371/journal. pone.0159036

36. Aleksandrov Yu. I. Differentiation and development. In: Teoriya razvitiya: Differentsionno-integratsionnaya paradigm [Developmental theory: Differentiation-integration paradigm]. Moscow, Yazyki slavyanskikh kul'tur, 2009, pp. 19-28.

37. Aleksandrov Yu. I. Regressiya [Regression]. Tezisy dokladov: 7-ya mezhdunarodnaya konferentsiya po kognitivnoi nauke [Proc. the 7th International Conference on Cognitive Science]. Moscow, Institute of Psychology RAS Publ., 2016, pp. 100-101.

38. Aleksandrov Yu. I., Svarnik O. E., Znamenskaya I. I., Kolbeneva M. G., Arutyunova K. R., Krylov A. K., Bulava A. I. Regressiya kak etap razvitiya [Regression as a stage of development]. Moscow, Institute of Psychology RAS Publ., 2017. $191 \mathrm{p}$.

39. Aleksandrov Yu. I., Svarnik O. E., Znamenskaya I. I., Kolbeneva M. G., Arutyunova K. R., Krylov A. K., Bulava A. I. Alcoholization as a condition of regression in learning and prosocial behavior. Voprosy psikhologii, 2017, no. 3, pp. 80-91 (in Russian). 
40. Aleksandrov Yu. I., Svarnik O. E., Znamenskaya I. I., Kolbeneva M. G., Arutyunova K. R., Krylov A. K., Bulava A. I. Stress, disease, and learning as conditions for regression. Voprosy psikhologii, 2017, no. 4, pp. 87-101 (in Russian).

41. Aleksandrov Yu. I. Cognition as systemogenesys. Anticipation: Learning from the Past: The Russian/Soviet Contributions to the Science of Anticipation. New York: Springer, 2015, Vol. 25, pp. 193-220.DOI: 10.1007/978-3-319-19446-2 11

42. Apanovich V. V., Znakov V. V., Aleksandrov Yu. I. Testing the analytic-holistic scale in a Russian sample. Voprosy psikhologii, 2017, Vol. 38, no. 5, pp. 80-96 (in Russian). DOI: $10.7868 /$ S0205959217050075

43. Aleksandrov Yu. I., Kirdina S. G. Mentality types and institutional matrices: Multi-disciplinary approach. Sotsiologicheskie issledovaniya (Sotsis) - Sociological Studies (Socis), 2012, no. 8, pp. 3-12 (in Russian).

44. Alexandrov Yu., Kirdina S. Toward integration of social mental and institutional models: systemic approach. Montenegrin Journal of Economics, 2013, Vol. 9, no. 1, pp. 7-15. Available at: http://repec.mnje.com/mje/2013/v09-n01/ mje 2013 v09-n01-a11.html (Accessed 08 August 2018).

45. Apanovich V. V., Bezdenezhnykh B. N., Znakov V. V., Sams M., Yaaskelainen I., Aleksandrov Yu. I. Differences of the brain activity in individual, competitive and cooperative behavior between subjects with analytic and holistic cognitive styles. Eksperimental'naya psikhologiya-Experimental psychology, 2016, Vol. 9, no. 2, pp. 5-22 (in Russian). DOI: $10.17759 /$ exppsy.2016090202

46. Apanovich V. V., Bezdenezhnykh B. N., Sams M., Jääskeläinen I. P., Alexandrov Yu. I. Event-related potentials during individual, cooperative, and competitive task performance differ in subjects with analytic vs. holistic thinking. International Journal of Psychophysiology, 2018, Vol. 123, Issue 1, pp. 136-142. DOI: 10.1016/j.ijpsycho.2017.10.001

47. Arutyunova K. R., Aleksandrov Yu. I. Factors of gender and age in moral judgment of actions. Psikhologicheskii zhurnal, 2016, Vol. 37, no. 2, pp. 79-91 (in Russian). DOI: 10.7868/S0205959217050075

48. Arutyunova K. R., Alexandrov Yu. I., Hauser M. D. Sociocultural influences on moral judgments: East-West, male-female, and young-old. Frontiers in Psychology, 2016, Vol. 7, no. 1334, pp. 1-15. DOI: 10.3389/fpsyg.2016.01334.

49. Arutyunova K. R., Bakhchina A. V., Aleksandrov Yu. I. The effects of alcohol on heart rate and evaluation of actions in moral dilemmas. Eksperimental'naya psikhologiya - Experimental Psychology, 2017, Vol. 10, no. 1, pp. 5-22 (in Russian). DOI: 10.17759/exppsy.2017100102

50. Bakhchina A. V., Alexandrov Yu. I. Heart rate complexity during the temporary systems dedifferentiation. Eksperimental'naya psikhologiya - Experimental psychology, 2017, Vol. 10, no. 2, pp. 114-130 (in Russian). DOI: $10.17759 /$ exppsy.2017100210 
51. Bakhchina A. V., Arutyunova K. R., Sozinov A. A., Demidovsky A. V., Alexandrov Y. I. Sample entropy of the heart rate reflects properties of the system organization of behaviour. Entropy, 2018, Vol. 20, no. 6, p. 449 (1-22). DOI: 10.3390/e20060449

52. Sozinova I. M., Sozinov A. A., Laukka S. J., Alexandrov Yu. I. The prerequisites of prosocial behavior in human ontogeny. International Journal of Cognitive Research in Science, Engineering and Education (IJCRSEE), 2017, Vol. 5, no. 1, pp. 57-63. DOI: 10.5937/IJCRSEE1701057S

53. Sozinova I. M., Bakhchina A. V., Aleksandrov Yu. I. Dynamics of heart activities during moral dilemmas solving by children aged 4-11. Eksperimental'naya psikhologiya - Experimental Psychology, 2017, Vol. 10, no. 3, pp. 97-109 (in Russian). DOI: 10.17759/exppsy.2017100307

54. Sozinova I. M., Peskova P. A., Aleksandrov Yu. I. Own/alien moral dilemmas solving by children aged 4-11 in the absence of a visible external control. Voprosy psikhologii, 2018, no. 2, pp. 53-63 (in Russian).

55. Znamenskaya I. I., Markov A. V., Bakhchina A. V., Aleksandrov Yu. I. The attitudes toward out-group in the stress: system dedifferentiation. Psikhologicheskii zhurnal, 2016, Vol. 37, no. 4, pp. 44-58 (in Russian).

56. Krylov A. K. Psikhofiziologicheskii analiz reflektornogo vzaimodeistviya so sredoi [Psychophysiological analysis of a reflective interaction with the environment]. Diss. Cand. Sci. (Psych.). Moscow, 2007. 208 p.

57. Krylov A. K., Aleksandrov Yu. I. Immersion in the environment as an alternative to the method of stimulus presentation: A model study. Psikhologicheskii zhurnal, 2007, Vol. 28, no. 2, pp. 106-113 (in Russian).

58. Krylov A. K. Aktualizatsiya opyta kak vozmozhnaya prichina fraktal'noi struktury poiskovogo povedeniya [Actualization of experience as a possible cause of the fractal structure of searching behavior]. Trudy $V$ Vserossiiskoi konferentsii: Nelineinaya dinamika v kognitivnykh issledovaniyakh-2017 [Proc. the V All-Russian Conference "Nonlinear dynamics in cognitive studies 2017"]. Nizhny Novgorod, Institute of Applied Physics RAS Publ., 2017, pp. 128-131. 